\title{
ROLA, ZNACZENIE I WPŁYW PARTNERSTWA PUBLICZNO-PRYWATNEGO W ZAKRESIE ZADAŃ WŁASNYCH SAMORZĄOÓW NA INTERDYSCYPLINARNE PODEJŚCIE W REALIZACJI ZADAŃ PUBLICZNYCH
}

\section{THE ROLE, SIGNIFICANCE AND IMPACT OF PUBLIC-PRIVATE PARTNERSHIP IN THE SCOPE OF OWN TASKS OF LOCAL GOVERNMENTS ON CROSS-DISCIPLINARY APPROACH IN THE IMPLEMENTATION OF PUBLIC TASKS}

\section{Streszczenie}

Wyzwaniem stojącym przed administracją publiczną jest zapewnienie realizacji zadań publicznych w sposób skuteczny i efektywny oraz racjonalne gospodarowanie środkami publicznymi. Dążenie do skuteczności i efektywności prowadzić powinno do szukania rozwiązań optymalnych w zakresie form organizacyjno-prawnych, jak i metod realizacji oraz finansowania zadań publicznych. Optymalizacja wymaga jednak podejścia kompleksowego do szeregu zagadnień związanych z realizacją zadań publicznych. W referacie podjęto próbę wskazania uwarunkowań optymalnej realizacji zadań publicznych. Ponadto przedstawiono modele realizacji zadań publicznych, które w różnym stopniu adoptują rozwiązania prowadzące do skuteczności i efektywności. 
Słowa kluczowe: partnerstwo publiczno-prywatne; samorząd terytorialny; zadania publiczne; skuteczność; efektywność; optymalizacja.

\begin{abstract}
It is a challenge for public authorities to ensure the implementation of public tasks in an effective, efficient and rational management of public funds. The pursuance for efficiency and effectiveness should lead to a search for optimal solutions in terms of organizational and legal forms as well as methods of implementation and funding of public tasks. Such optimization requires a comprehensive approach to the range of issues related to the implementation of public tasks. The paper attempts to identify the optimal conditions for the implementation of public tasks. In addition, it presents models of public tasks, which in varying degrees adopt measures leading to the effectiveness and efficiency.
\end{abstract}

Keywords: public-private partnership; local government; public tasks; effectiveness; efficiency; optimization.

\title{
1. Wprowadzenie
}

Realizacja zadań publicznych, w tym proces zapewnienia dóbr publicznych, to system złożony. Zrozumienie mechanizmów składających się na ten system jest kluczem do optymalizacji realizacji zadań publicznych. Postawić można tezę, że istnieją prawidłowości, które mają wpływ na skuteczność i efektywność oraz racjonalne gospodarowanie w wydatkowaniu środków publicznych. Podstawę gospodarności, efektywności i skuteczności należy - według autora - w pierwszej kolejności upatrywać w mechanizmach i procesach występujących przy realizacji zadań publicznych, a następnie w formach organizacyjno-prawnych adoptujących w mniejszym lub większym stopniu określone mechanizmy i procesy. Z problemami tymi przychodzi zmierzyć się każdemu kto zajmuje się tymi zagadnieniami od strony teoretycznej, jak i praktycznej. Motywem podjęcia tematu w zakresie kompleksowego i interdyscyplinarnego podejścia do realizacji zadań publicznych jest problem marnotrawstwa i złego gospodarowania zasobami publicznymi.

Zrozumienie istoty zarysowanego zagadnienia oraz występujących dysfunkcji w zarządzaniu i wydatkowaniu środków publicznych upatrywać należy w braku znajomości uwarunkowań optymalnej realizacji zadań publicznych lub oporu do kompleksowego rozpatrywania zagadnień związanych 
z realizacją tych zadań. Próba znalezienia rozwiązania tego problemu wymaga: 1. przedstawienia metod realizacji i finansowania zadań publicznych oraz form organizacyjno-prawnych wykorzystywanych do tego celu; 2 . omówienia uwarunkowań optymalnej realizacji zadań publicznych. Znajomość zasad funkcjonowania jednostek oraz podmiotów działających w określonych formach organizacyjno-prawnych, a także procesów zachodzących w realizacji zadań publicznych stanowi podstawę do wskazania takich rozwiązań, które zapewnią kompleksowe ujęcie wszystkich zagadnień z tym związanych.

\section{Formy organizacyjno-prawne, tryby i modele wykorzystywane w realizacji zadań publicznych}

Jednostki samorządu terytorialnego ${ }^{1}$ mogą wykonywać zadania własne w systemie własnym lub zleconym. Wykorzystują w tym celu różne modele finansowania oraz realizacji zadań. Ponadto korzystają z różnych form organizacyjno-prawnych. Samorządy mogą wykonywać zadania własne w następujących formach:

1. w formie jednostki budżetowej,

2. w formie samorządowego zakładu budżetowego,

3. w formie samorządowej osoby prawnej,

4. w formie spółki prawa handlowego,

5. w formie spółdzielni,

6. w formie zlecenia zadań.

Realizacja zadań własnych JST odbywać się może poprzez własne jednostki organizacyjne oraz komunalne podmioty posiadające osobowość prawną. Zadania wykonywane przez jednostki organizacyjne nie posiadające osobowości prawnej wykonują zadania samorządów zgodnie: a) z uchwałami organów stanowiących JST o utworzeniu danej jednostki, b) z uchwałami budżetowymi oraz wieloletnią prognozą finansową, w których to dokumentach są wskazane i przypisane im określone zadania budżetowe. Natomiast osoby prawne mogą realizować zadania publiczne w trybie powierzenia lub zlecenia.

Ponadto wykonywanie zadań własnych może być realizowane poprzez zawieranie umów z innymi podmiotami posiadającymi osobowość prawną. JST realizację zadań publicznych może zlecić w trybie:

1 Jednostki samorządu terytorialnego - gminy, powiaty, województwa; w dalszej części artykułu dla ich określenia używany jest skrót JST. 
a. Prawa zamówień publicznych ${ }^{2}$,

b. pożytku publicznego ${ }^{3}$,

c. partnerstwa publiczno-prywatnego ${ }^{4}$,

d. koncesji na roboty budowlane lub usługi ${ }^{5}$,

e. innym (ustaw szczególnych np. ustawy o publicznym transporcie zbiorowym ${ }^{6}$ ).

W obecnym systemie prawnym wskazać można na trzy generalne modele rozwiązań organizacyjno-prawnych do realizacji zadań publicznych:

1. model realizacji zadań w formule budżetowej, poprzez jednostkę budżetową lub samorządowy zakład budżetowy,

2. model realizacji zadań poprzez spółkę komunalną lub inną samorządową osobę prawną,

3. model realizacji zadań w formule partnerstwa publiczno-prywatnego lub koncesji.

Wybór określonego modelu wiąże się z przyjęciem określonej struktury realizacji zadań publicznych. Każdy z tych modeli charakteryzuje się określonym sposobem funkcjonowania. W zależności od przyjętego modelu zadania publiczne realizowane są w sposób kompleksowy lub fragmentaryczny (tj. podzielone są na etapy, fazy, części). Wynika to ze specyfiki przyjętego systemu zarządzania realizacją zadań publicznych w poszczególnych formach organizacyjno-prawnych. Inaczej wygląda on w jednostce budżetowej oraz samorządowym zakładzie budżetowym, a inaczej proces ten przebiega w spółce komunalnej lub innej publicznej osobie prawnej. Mankamentem tych jednostek jest dzielenie zadań publicznych na etapy i części. Ponadto koncentrowanie się na produktach, a nie generalnych celach, które powinny zostać osiągnięte poprzez realizację określonych zadań.

Negatywne doświadczenia z realizacji zadań publicznych w formule budżetowej (jednostki budżetowej, samorządowego zakładu budżetowego) oraz nie zawsze spełnione oczekiwania realizacji tych zadań poprzez spółkę

2 Ustawa z dnia 29 stycznia 2004 r. Prawo zamówień publicznych (tekst jedn. Dz.U. z 2015 r., poz. 2164).

3 Ustawa z dnia 23 kwietnia 2003 r. o działalności pożytku publicznego i o wolontariacie (tekst jedn. Dz.U. z 2016 r., poz. 239 ze zm.).

4 Ustawa z dnia 19 grudnia 2008 r. o partnerstwie publiczno-prywatnym (tekst jedn. Dz.U. z 2015 r., poz. 696 ze zm.).

5 Ustawa z dnia 9 stycznia 2009 r. o koncesji na roboty budowlane lub usługi (tekst jedn. Dz.U. z 2015 r., poz. 113).

6 Ustawa z dnia 16 grudnia 2010 r. o publicznym transporcie zbiorowym (tekst jedn. Dz.U. z 2015 r., poz. 1440 ze zm.). 
komunalną prowadzą do poszukiwania metod urynkowienia dostarczania usług publicznych. Ogólnie funkcjonuje bowiem pogląd, że dobra oraz usługi publiczne dostarczane i świadczone przez komunalne jednostki organizacyjne są relatywnie droższe oraz gorszej jakości, w porównaniu do sektora prywatnego $^{7}$. Podstawową ideą jest przekonanie, że komercjalizacja sprzyja poprawie efektywności realizacji zadań publicznych, wprowadzeniu nowych rozwiązań technicznych oraz technologicznych, wprowadzeniu biznesowych metod zarządzania i organizacji w wykonywaniu zadań publicznych, wprowadzeniu nowych metod finansowania, poszukiwaniu optymalizacji podatkowej oraz zwróceniu szczególnej uwagi na kwestie prawne regulujące relacje pomiędzy sektorem publicznym a prywatnym.

W przeciwieństwie do wskazanych form, w diametralnie inny sposób działają mechanizmy i procesy przy wykonywaniu zadań publicznych w podmiocie powołanym do realizacji zadań w formule PPP. Istota i konstrukcja prawna PPP determinuje konieczność zintegrowanego podejścia do określonego zadania publicznego.

\section{Uwarunkowania optymalnej realizacji zadań publicznych}

Prawidłowa realizacja zadań publicznych wymaga - według autora - uwzględnienia:

a. całego procesu realizacji zadania - podzielonego na etapy,

b. obszarów tematycznych - podzielonych na zagadnienia.

W procesie zapewnienia dobra publicznego uwzględnić należy etapy następujących po sobie zdarzeń oraz zestaw zagadnień przyporządkowanych do obszarów tematycznych. Podstawą kompleksowego podejścia do realizacji zadań publicznych jest struktura zintegrowana w ramach jednolitego systemu, w której wszystkie elementy są ze sobą powiązane i uwzględniają całość procesu zapewnienia dóbr publicznych. Zdefiniowanie takiej struktury wymaga przejścia od modelu funkcjonalnego (w którym funkcja odnosi się tylko do części a nie do całości) do centralizacji federacyjnej, czyli stworzenia organizacji wokół autonomicznego „biznesu” związanego z danym produktem.

$7 \quad$ Z. Dolewska, Zarzadzanie w jednostkach organizacyjnych gminy, artykuł dostępny on-line na stronie: http://www.ue.katowice.pl/fileadmin/_migrated/content_uploads/3_Z.Dolewka_Zarzadzanie_w_jednostkach_organizacyjnych_gminy.pdf (dostęp: 30.06.2016 r.). 
Przyjmując założenie, że realizację zadania publicznego traktować należy, jako projekt stanowiący element programu działania władzy publicznej w określonej sferze zadań publicznych - to w dostarczaniu dóbr publicznych wskazać należy na następujące etapy: a. diagnozę (identyfikacja stanu, kierunków rozwoju, potrzeb); b. określenie celu realizacji zadania publicznego (wskazanie celu generalnego i celów szczegółowych); c. koncepcje (wskazanie sposobów osiągnięcia celu); d. planowanie (wskazanie wariantu i wybór wariantu optymalnego); e. produkcja (budowa, przebudowa); f. utrzymanie (czynności obejmujące eksploatacje i konserwacje oraz prace odtworzeniowe); g. zamknięcie (zakończenie trwałości dobra publicznego lub odstąpienie od realizacji zadania publicznego); h. ewaluacja ex post (ocena zadania). Realizacja zadania publicznego to zatem proces określonych czynności. Procesy te wiążą się ze sobą poprzez przekazywanie wartości dodanej charakterystycznej dla kolejnych etapów. Stanowią zintegrowany łańcuch procesów, które się wzajemnie przenikają, a czynności wykonane w jednej fazie mają wpływ na czynności w kolejnych etapach. Według H. Hinterhubera, jak podaje R. Matwiejczuk, proces to całość zintegrowanych i przenikających funkcje czynności, za pomocą których jest kreowany produkt lub usługa (wartość), stosownie do wymogów wewnętrznych i zewnętrznych klientów ${ }^{8}$.

Podmiot publiczny powinien odpowiadać przede wszystkim za określenie celów, które mają być osiągnięte z punktu widzenia interesu publicznego oraz za zagwarantowanie jakości świadczonych usług i politykę cenową. Natomiast zadania partnera prywatnego winny koncentrować się wokół procesu inwestycyjnego, jego planowania, realizacji i następnie zarządzania, świadczenia usług publicznych lub utrzymania składników majątkowych.

W procesie zapewnienia dobra publicznego, poza koniecznością uwzględnienia następujących po sobie etapów, wymagane jest również uwzględnienie szeregu zagadnień, które - według autora - przedstawić można w pięciu obszarach tematycznych: a. obszar merytoryczny; b. obszar ekonomiczny; c. obszar finansowy; d. obszar organizacyjny; e. obszar prawny. W ramach poszczególnych obszarów wyodrębnić można zagadnienia, o różnym stopniu ważności, ale mających wpływ na realizację zadania publicznego:

1. obszar merytoryczny dotyczy:

a. charakterystyki zadania (opis przedsięwzięcia),

8 Cyt. za: R. Matwiejczuk, Zarzadzanie marketingowo-logistyczne-wartość i efektywność, Warszawa 2006, s. 66. 
b. kwestii technicznych,

c. zagadnień technologicznych,

2. obszar ekonomiczny obejmuje zagadnienia:

a. efektywności makroekonomicznej,

b. efektywności mezoekonomicznej,

c. efektywności mikroekonomicznej

3. obszar finansowy związany jest z kwestiami:

a. metod finansowania,

b. wyceny zadania,

c. identyfikacji i wyceny ryzyk,

4. obszar organizacyjny dotyczy:

a. formy organizacyjno-prawnej,

b. modelu zarządzania oraz kontroli i nadzoru,

c. harmonogramu realizacji,

5. obszar prawny obejmuje kwestie:

a. kontraktów $\mathrm{z}$ wykonawcami i podwykonawcami,

b. relacji prawnych $\mathrm{z}$ interesariuszami przedsięwzięcia,

c. zagadnień podatkowych.

Scalenie w jedną strukturę rozproszonych obszarów oraz zagadnień stwarza większe możliwości zidentyfikowania problemów i zdarzeń mogących wystąpić w poszczególnych etapach procesu realizacji zadania, niż przy ich rozproszeniu. Łączne użycie pięciu obszarów zmienia zasadniczo sposób realizacji zadań publicznych. Daje możliwość sprawnego sterowania i zarządzania poszczególnymi fazami, etapami, łącząc wszystkie fazy i obszary w jedną spójną całość. Zaprezentowana struktura realizacji zadania publicznego stanowi funkcjonalny łańcuch wartości obejmujący procesy związane z zapewnieniem dobra publicznego. Stwarza to możliwość koordynacji w celu uzyskania optymalnego rozwiązania. Łańcuch powiazań faz i obszarów można traktować, jako zintegrowany proces składający się z procesów cząstkowych w ścisły sposób ze sobą powiązanych. Dzięki temu uzyskuje się zintegrowany system zarządzania w realizacji zadania publicznego. Wymaga to jednak zachowania i przestrzegania dwóch reguł:

1. traktowania zadania publicznego, jako całości, a nie zbioru osobnych segmentów,

2. zarządzanie takie wymaga nowego podejścia polegającego na integracji faz i obszarów, a nie wyłącznie ich połączenia. 
Rozwiązanie takie jest wyrazem kompleksowego rozpatrywania realizacji zadań publicznych i zapewnienia dóbr publicznych. Cała struktura zorientowana jest na osiągnięcie założonego celu, a nie tylko wytworzenie produktów. Orientacja na rezultaty poprzez procesy i obszary powinna prowadzić do optymalizacji nakładów ponoszonych przy realizacji zadań publicznych i uzyskania zamierzonych celów. Przedstawiony zarys uwarunkowań optymalnej realizacji zadań publicznych najpełniej adoptowany jest przy realizacji zadań w formule PPP.

\section{Wpływ konstrukcji PPP na kompleksowe podejścia do realizacji zadań publicznych}

Z przeprowadzonej analizy realizacji zadań publicznych przy wykorzystaniu wskazanych form organizacyjno-prawnych wynika, że optymalnym rozwiązaniem jest realizacja zadań w formule PPP poprzez spółkę celową. Rozwiązanie to zapewnia całościowe uwzględnienie wszystkich etapów realizacji zadań publicznych oraz zagadnień z tym związanych. Stan taki jest konsekwencją konstrukcji PPP, dla której główną osią jest kontrakt między stroną publiczną a prywatną.

Wymagania prawne dotyczące umowy o PPP uregulowano w rozdziale 3 ustawy o partnerstwie publiczno-prywatnym. W przeciwieństwie do ustawy o PPP z 2005 r. ${ }^{9}$, na co zwracają uwagę m.in. K. Płonka-Bielenin i T. Moll, ustawodawca w art. 7 ustawy o PPP z 2008 nie wskazał essentialia negotii, czyli przedmiotowo istotnych elementów umowy o $\mathrm{PPP}^{10}$.

Kontrakt PPP determinuje konieczność uwzględnienia kompleksowo w jednym dokumencie wszystkich zagadnień związanych z dostarczeniem dobra publicznego, a następnie jego utrzymania. Wdrożenie PPP wymaga solidnych ram prawnych oraz precyzyjnych kontraktów, które regulować będą zakres przedsięwzięcia, koszty i korzyści, ryzyka oraz wszystkie potencjalne zdarzenia, które mogą mieć wpływ na dany projekt.

Istota różnicy pomiędzy tradycyjnymi formami realizacji zadań publicznych, a realizacją zadań w formule PPP to zrozumienie różnicy między zwykłą

9 W art. 18 ustawy o PPP z 2005 r. ustawodawca określił główne postanowienia umowy (essentialia negotii), które powinny znaleźć się w każdej umowie o partnerstwie publiczno-prywatnym.

10 K. Płonka-Bielenin, T. Moll, Partnerstwo publiczno-prywatne-komentarz do ustawy o partnerstwie publiczno-prywatnym, Warszawa 2012, s. 104. 
umową na wykonawstwo a kontraktem PPP. Różnice te wymagają innego podejścia do zarządzania umową i samym przedsięwzięciem. W umowie o zamówienie publiczne - jak podaje K. Płonka-Bielenin - zamawiający zobowiązuje się do świadczenia pieniężnego, natomiast wykonawca do świadczenia niepieniężnego i w tym sensie umowa o zamówienie publiczne jest ,jednostronna"11. W przypadku umowy o PPP nie można przypisać takiej prostej konstrukcji ponieważ współpraca nie ogranicza się wyłącznie do nabycia usługi w zamian za ustaloną zapłatę ${ }^{12}$. Ponadto zarządzanie umowami, zarówno po stronie publicznej jak i prywatnej, polega na monitorowaniu, ewaluacji zdarzeń zaplanowanych, przewidywaniu zdarzeń mogących wystąpić w przyszłości i reagowanie na zdarzenia mogące wystąpić w trakcie realizacji. Ważnym zagadnieniem, z punktu widzenia kontraktu PPP, jest kwestia zarządzania relacjami między stronami kontraktu. Powody złego zarządzania umowami to: niskiej jakości umowy, brak postawy partnerskiej, różnice pod względem umiejętności i doświadczeń zespołów po stronie publicznej i prywatnej, i jak zawsze starcia osobowości pomiędzy członkami zespołów. Ponadto brak monitorowania projektu i zarządzania ryzykiem. Wśród zalet poprawnie skonstruowanego partnerstwa publiczno-prywatnego B. Korbus i M. Strawiński wymieniają: przyspieszenie procesów inwestycyjnych w zakresie infrastruktury, szybsze wdrożenie projektów, obniżenie całkowitych kosztów przedsięwzięcia, zachętę do sprawnej realizacji zadań, polepszenie jakości usług świadczonych w ramach PPP, generowanie dodatkowych przychodów, polepszenie jakości administracji publicznej oraz lepszą alokację ryzyka związanego z realizacją przedsięwzięcia ${ }^{13}$. Natomiast M. Moszoro wymienia osiem potencjalnych korzyści z PPP:

1. partner prywatny zapewnia stronie publicznej do kapitału, a tym samym odciąża częściowo sektor publiczny od kosztów inwestycyjnych;

2. w fazie budowy stosuje się nowoczesne technologie na większą skalę niż w trakcie realizacji inwestycji przez podmiot publiczny, dzięki czemu można ograniczać całkowite koszty przedsięwzięcia, nawet jeżeli ważony koszt kapitału okazuje się wyższy niż w wypadku publicznego finansowania;

11 Tamże, s. 105. Zob. szerzej: druk sejmowy (VI kadencja) nr 1180 z dnia 20.10.2008 r. rządowy projekt ustawy o partnerstwie publiczno-prywatnym, s. 6, http://orka.sejm.gov. pl/Druki6ka.nsf (dostęp: 30.06.2016 r.).

12 K. Płonka-Bielenin, T. Moll, Partnerstwo publiczno-prywatne..., s. 105.

13 Zob. szerzej: B. Korbus, M. Strawiński, Partnerstwo publiczno-prywatne-nowa forma realizacji zadań publicznych, Warszawa 2009, s. 101-104. 
3. sprawne zarządzanie inwestycją i dostępnymi zasobami przyczynia się do skrócenia czasu rozwoju inwestycji;

4. w fazie operacyjnej doświadczenie podmiotów prywatnych przyczynia się do zmniejszenia kosztów operacyjnych;

5. efektywne zarządzanie marketingowo-logistyczne pozwala zwiększyć przychody operacyjne;

6. strona prywatna ma większe doświadczenie w negocjowaniu kontraktów $\mathrm{z}$ instytucjami finansowymi oraz stosowania różnego rodzaju instrumentów i konstrukcji finansowych;

7. sprywatyzowane przedsiębiorstwo użyteczności publicznej poddane jest większej presji opinii publicznej, żeby prowadzić działalność jawnie i na zrozumiałych zasadach opartych na rachunku ekonomicznym, niż przedsiębiorstwo publiczne;

8. następuje ograniczenie wpływów politycznych na decyzje gospodarcze, dzięki temu podmioty wykonujące zadania cieszą się większą samodzielnością i mają większą elastyczność ${ }^{14}$.

\section{Podsumowanie}

Komplementarne i interdyscyplinarne podejścia do realizacji zadania publicznego nie jest oczywiście zastrzeżone wyłącznie dla formuły PPP. Jednak, jak zostało to przedstawione, to zawarcie długoterminowej umowy determinuje konieczność całościowego uwzględnienia wszystkich zagadnień. Dzięki temu zadania publiczne mogą być realizowane w sposób spójny. Stwarza to również możliwość uzyskania optymalnego rozwiązania w zapewnieniu dobra publicznego. Przede wszystkim jednak daje możliwość osiągnięcia założonego celu, a nie tylko wytworzenie i dostarczenie produktów. W PPP należy zatem upatrywać rozwiązań gwarantujących kompleksową realizację zadań publicznych. Z uwagi na fakt, że PPP nie zawsze znajdzie zastosowania we wszystkich sferach publicznych powinna zostać podjęta próba adoptowania wypracowanych wzorców do tradycyjnych, dotychczas wykorzystywanych form realizacji zadań publicznych. Zapewniając kompleksowe podejście do realizacji zadań publicznych osiągnąć można skuteczność i efektywność oraz gospodarność w wydatkowaniu środków publicznych.

14 Zob. szerzej: M. Moszoro, Partnerstwo publiczno-prywatne w sferze użyteczności publicznej, Warszawa 2010, s. 62-66. 


\section{Literatura}

1. Dolewska Z., Zarzadzanie w jednostkach organizacyjnych gminy, http://www.ue.katowice.pl/ fileadmin/_migrated/content_uploads/3_Z.Dolewka_Zarzadzanie_w_jednostkach_organizacyjnych_gminy.pdf (dostęp: 30.06.2016 r.).

2. Korbus B., Strawiński M., Partnerstwo publiczno-prywatne-nowa forma realizacji zadań publicznych, LexisNexis, Warszawa 2009.

3. Matwiejczuk R., Zarządzanie marketingowo-logistyczne-wartość i efektywność, Wydawnictwo C.H. Beck, Warszawa 2006.

4. Moszoro M., Partnerstwo publiczno-prywatne w sferze użyteczności publicznej, Oficyna a Wolters Kluwer business, Warszawa 2010.

5. Płonka-Bielenin K., Moll T., Partnerstwo publiczno-prywatne - komentarz do ustawy o partnerstwie publiczno-prywatnym, Difin, Warszawa 2012.

Pawel Adamczyk

Urząd Marszałkowski Województwa Kujawsko-Pomorskiego 